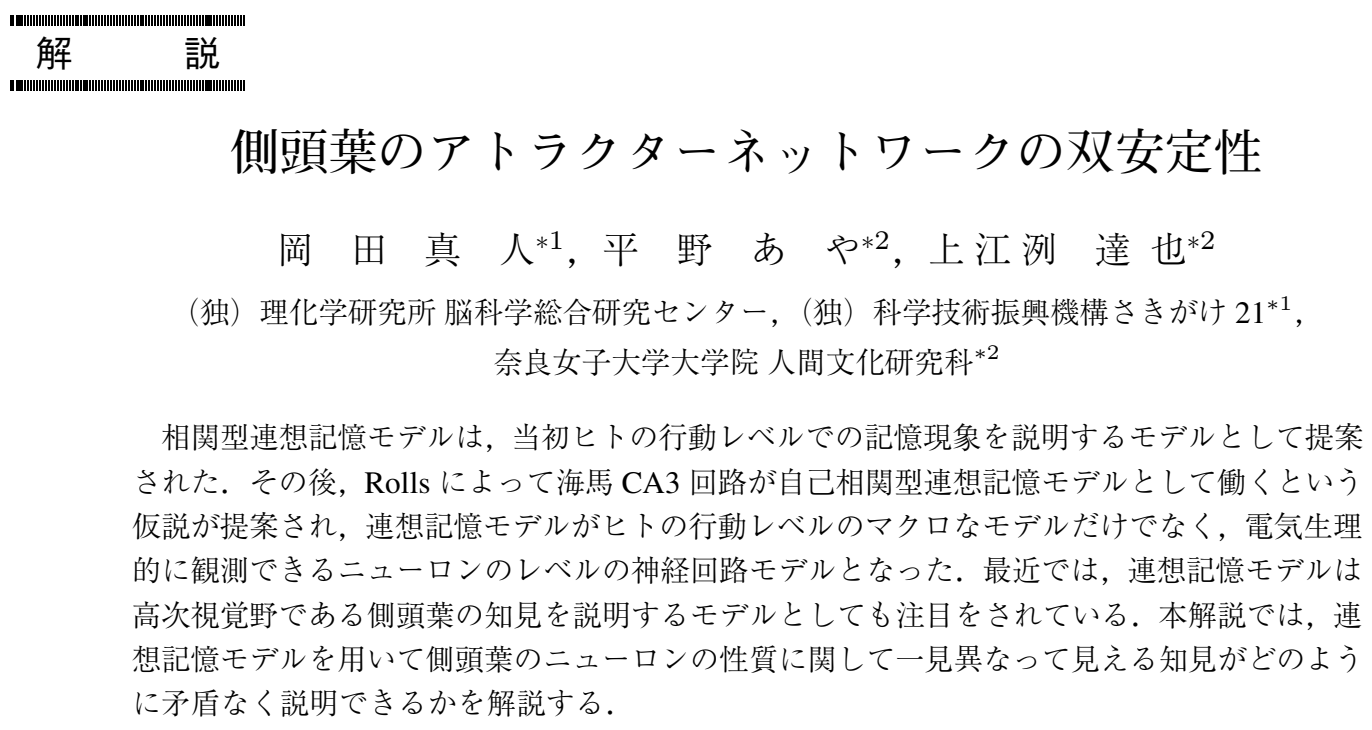

1. はじめに

視覚の最終段階とされている側頭葉のニューロンの 神経生理学的な特性には未だ謎な点が多い ${ }^{1 \sim 5)}$.今回は その一つの例として，二つの知見について紹介する. Tanaka らや Fujita らはシングルセルレコーディングを 用いて, 側頭葉の細胞は視覚物体の部分的な特徵に選 択的に反応することを示した ${ }^{1,4)}$. 一方, Gross のグルー プの Gochin らは，視覚的にまったく異なった刺激セッ 卜をもちいてニューロンの応答を調べた5). その結果, ニューロンの応答の選択性は弱く, 多くのニューロン はすべての刺激に応答し，ニューロン間の違いは発火 率が異なるという定量的なものであった. サルの麻酔. 無麻酔の状態などが，この矛盾を説明する仮説として は用いられているが，それ以上明解な答はえられてい ない.

上の矛盾は側頭葉を単なる画像フィルターとして捉 えたために生じたものである。側頭葉を含む視覚系が 力学系を構成しており, アトラクターを使って視覚計 算を行なっているとしよう。この場合，アトラクター の引き込み領域をまたぐように入力が変化した場合, それに応じて神経系が定性的に異なった応答が生じて も何ら不思議はない。ここでは, Amitらによって提案 されたアトラクターニューラルネットワークモデル6,7) を用い，その数理的な性質を解析することにより，側 頭葉のニューロンに関する, いくつかの電気生理学的 な実験結果の解釈と新たな実験の提案を行なう.

\footnotetext{
$* 1 \mp 351-0198$ 埼玉県和光市広沢 2-1

$* 2=630-8506$ 奈良県奈良市北魚屋東町
}

\section{2. 定式化}

\section{1 モデル}

モデルは相互に結合している \pm 1 の 2 状態をとる $N$ 個のニューロンから構成されているとする， $i$ 番目の ニューロンの状態を $S_{i}$ とする. 本論文では, モデルの ダイナミクスとして, 有限温度での非同期更新を用い る. 非同期更新では, まず $N$ 個のニューロンからラン ダムにニューロンを一つ選ぶ. たとえば $i$ 番目のニュー ロンが選ばれたとしよう。つぎに $i$ 番目のニューロン への入力 $h_{i}$,

$$
h_{i}=\sum_{j \neq i}^{N} J_{i j} S_{j},
$$

を計算する．ここで $J_{i j}$ は $j$ 番目のニューロンから $i$ 番目のニューロンへの結合荷重である.この入力 $h_{i}$ を 用いて $i$ 番目のニューロンの状態が $S_{i}= \pm 1$ となる確 率を以下のようにする，

$$
\operatorname{Prob}\left[S_{i}= \pm 1\right]=\frac{1 \pm \tanh \left(\beta h_{i}\right)}{2} .
$$

ここで, $\beta=1 / T$ は温度 $T$ によって決まる. 温度 $T=0(\beta \rightarrow \infty)$ の極限では,

$$
S_{i}=\operatorname{sgn}\left(\sum_{j \neq i}^{N} J_{i j} S_{j}\right),
$$

となる。この手続きを $N$ 回繰り返すことを 1 モンテ カルロステップ (MCS) と呼ぶ.

モデルには $2 s+1$ 個のパターンを以下の方法で記憶 
する. $\mu$ 番目のパターン $\boldsymbol{\xi}^{\mu}(-s \leq \mu \leq s)$ を以下の確 率でランダムに決定し,

$$
\operatorname{Prob}\left[\xi_{i}^{\mu}= \pm 1\right]=\frac{1}{2}
$$

$j$ 番目のニューロンから $i$ 番目のニューロンへの結合 荷重 $J_{i j}$ を以下のように決める,

$$
\begin{aligned}
& J_{i j}=\frac{1}{N} \sum_{\mu=-s}^{s} \sum_{\nu=-s}^{s} \xi_{i}^{\mu} A_{\mu \nu} \xi_{j}^{\nu} \\
& A_{\mu \nu}=\delta_{\mu, \nu}+a \delta_{\mu-1, \nu}+a \delta_{\mu+1, \nu} .
\end{aligned}
$$

\section{2 モデルの生理学的な意義}

生理学的な立場でこのモデルの解説をしよう。この モデルは，Miyashita らの遅延見本合わせ課題で記憶 保持中の夕スクを行っているサルの側頭葉のニューロ ンが示す定常的な特性を説明するために提案されたモ デルである ${ }^{2,3,6,7)}$.この実験では，記憶する視覚刺激の 呈示の順番が近い刺激ほど，それらの視覚刺激は似た ニューロン活動を引き起こすことが示された。つまり, 視覚刺激の学習の順番という時間的な相関がニューロ ン集団の空間的な発火パターン間の相関に変換されて いたのである。Amitらは，このニューロン集団の空 間的な相関が生じるモデルを相関型の連想記憶モデル をもとに提案した。 $\$ 3.1$ で解説するように，このモデ ルには相関アトラクターとよばれるアトラクターが存 在する．相関アトラクターでは, 刺激の呈示順に相当 する記憶パターン番号に関してポピュレーションコー ディングが行なわれている。つまり，ある記憶パター ンが入力されると, そのパターンに対応するニューロ ンだけが反応するのではなく，そのとなりやさらにと なりの記憶パターンに対応するニューロンも応答し, その応答は記憶パターンの番号の差が大きくなると小 さくなるガウス分布状の特性を持つ. Amit らはこの性 質で Miyashita らの知見を説明したのである。相関ア トラクターは，ニューロンが作る高次元空間上に時間 軸という一次元的な構造を取り入れたうえで，その一 次元的な構造上に構成されたラインアトラクターもし くは孤立局在興奮と考えることができる。

\section{3 理論}

このモデルの平衡状態の性質を調べるために, 次の ハミルトニアンを持つ系を統計力学的に議論する, 本 論文では，ニューロン数 $N$ が無限大の極限を考え，パ ターン数 $(2 s+1)$ は $N$ に対して $O(1)$ である場合を 考える.

$$
H=-\frac{1}{2 N} \sum_{i \neq j}^{N} \sum_{\mu=-s}^{s} \sum_{\nu=-s}^{s} \xi_{i}^{\mu} A_{\mu \nu} \xi_{j}^{\mu} S_{i} S_{j},
$$

$$
\begin{aligned}
& Z=\operatorname{Tr}_{S} \exp (-\beta H), \\
& f=-\frac{1}{\beta N} \log Z .
\end{aligned}
$$

鞍点法を用いると，式 (8) の自由エネルギーは，

$$
\begin{aligned}
f= & -\frac{\beta}{2} \sum_{\mu, \nu} m_{\mu} A_{\mu \nu} m_{\nu}-i \sum_{\mu=1}^{p} m_{\mu} \hat{m}_{\mu} \\
& -\left\langle\left\langle\log 2 \cosh \left(-i \sum_{\mu=1}^{p} \hat{m}_{\mu} \xi^{\mu}\right)\right\rangle,\right.
\end{aligned}
$$

となり，鞍点を決めるオーダーパラメータ方程式は，

$$
\begin{aligned}
& \hat{m}_{\mu}=i \beta \sum_{\nu=-s}^{s} A_{\mu \nu} m_{\nu} \\
& m_{\mu}=\left\langle\left\langle\xi^{\mu} \tanh \beta\left(\sum_{\nu, \nu^{\prime}=-s}^{s} \xi^{\nu} A_{\nu \nu^{\prime}} m_{\nu^{\prime}}\right)\right\rangle,\right.
\end{aligned}
$$

となる.ここで〈く・》は(4)に従う $2 s+1$ 個の $\left\{\xi^{\mu}\right\}=$ $\xi^{-s}, \cdots, \xi^{0}, \cdots, \xi^{s}$ に関する平均操作をあらわす。式 (11)の $m_{\mu}$ の物理的な意味は, 平衡状態と $\mu$ 番目の記 憶パターンとのオーバーラップである,

$$
m_{\mu}=\frac{1}{N} \sum_{i=1}^{N} \xi_{i}^{\mu}\left\langle S_{i}\right\rangle \text {. }
$$

ここで $\left\langle S_{i}\right\rangle$ はニューロン $i$ の状態 $S_{i}$ の熱平均值で ある。

次に上で記述される平衡状態への想起ダイナミクス の理論を導出する。平衡状態はオーダーパラメーターで あるオーバーラップ $m_{\mu}$ で記述されるので, 時刻 $t$ で状 態 $\boldsymbol{S}$ がオーバーラップ $\left\{m_{\mu}\right\}=m_{-s}, \cdots, m_{0}, \cdots, m_{s}$ をとる確率,

$$
\begin{aligned}
& \mathcal{P}_{t}\left(\left\{m_{\mu}\right\}\right)=\operatorname{Tr}_{S} p_{t}(\boldsymbol{S}) \prod_{\mu=-s}^{s} \delta\left(m_{\mu}-m_{\mu}(\boldsymbol{S})\right), \\
& m_{\mu}(\boldsymbol{S})=\frac{1}{N} \sum_{i=1}^{N} \xi_{i}^{\mu} S_{i}
\end{aligned}
$$

を考える。ここで $p_{t}(\boldsymbol{S})$ は，時刻 $t$ に系が状態 $\boldsymbol{S}$ をと る確率である。式 (2) の状態更新則は, $S_{i}$ の遷移確率,

$$
w_{i}(\boldsymbol{S})=\frac{1-S_{i} \tanh \left[\beta \sum_{j \neq i}^{N} J_{i j} S_{j}\right]}{2},
$$

を用いて記述することができる。 これから $p_{t}(\boldsymbol{S})$ の従 うダイナミクスを記述するマスター方程式は，

$$
\frac{d}{d t} p_{t}(\boldsymbol{S})=\sum_{i=1}^{N}\left[p_{t}\left(F_{i} \boldsymbol{S}\right) w_{i}\left(F_{i} \boldsymbol{S}\right)-p_{t}(\boldsymbol{S}) w_{i}(\boldsymbol{S})\right]
$$


となる.ここでの時刻 $t$ の 1 単位時間は式 (2)の $1 \mathrm{MCS}$ に相当する． $F_{i}$ は状態 $\boldsymbol{S}$ の第 $i$ 成分 $S_{i}$ を反転させる スピンフリップ演算子である,

$$
F_{i} \boldsymbol{S}=\left(S_{1}, S_{2}, \cdots,-S_{i}, \cdots, S_{N}\right) .
$$

これから, 式 (13)の $\mathcal{P}_{t}\left(\left\{m_{\mu}\right\}\right)$ の従う式を求めると,

$$
\begin{aligned}
\frac{d}{d t} & \mathcal{P}_{t}\left(\left\{m_{\mu}\right\}\right) \\
& =\sum_{\nu=-s}^{s} \frac{\partial}{\partial m_{\nu}} \mathcal{P}_{t}\left(\left\{m_{\mu}\right\}\right)\left(m_{\nu}-\left\langle\left\langle\xi^{\nu} \tanh \beta h\right\rangle\right)\right. \\
h & =\sum_{\nu^{\prime}=-s}^{s} \sum_{\nu^{\prime \prime}=-s}^{s} \xi^{\nu^{\prime}} A_{\nu^{\prime} \nu^{\prime \prime}} m_{\nu^{\prime \prime}}
\end{aligned}
$$

となる。一方, 系は過渡的な状態でもオーバーラップ $\left\{m_{\mu}\right\}$ だけで記述できるので, $\mathcal{P}_{t}\left(\left\{m_{\mu}\right\}\right)$ は次のよう にも記述できる，

$$
\begin{aligned}
& \mathcal{P}_{t}\left(\left\{m_{\mu}\right\}\right)=\prod_{\mu=-s}^{s} \delta\left(m_{\mu}-m_{\mu}(t)\right) \\
& \frac{d}{d t} \mathcal{P}_{t}\left(\left\{m_{\mu}\right\}\right)=\sum_{\nu=-s}^{s} \frac{\partial}{\partial m_{\nu}} \mathcal{P}_{t}\left(\left\{m_{\mu}\right\}\right)\left(-\frac{d m_{\nu}}{d t}\right) .
\end{aligned}
$$

式 (18) と (20) を比較すると, 巨視的変数の時間発展 の方程式を得る,

$$
\frac{d}{d t} m_{\mu}=-m_{\mu}+\left\langle\left\langle\tanh \left(\beta \sum_{\nu, \nu^{\prime}=-s}^{s} \xi_{i}^{\nu} A_{\nu \nu^{\prime}} m_{\nu^{\prime}}\right)\right\rangle .\right.
$$

式 (21) の定常状態は平衡状態を記述する式 (11)に 一致する.

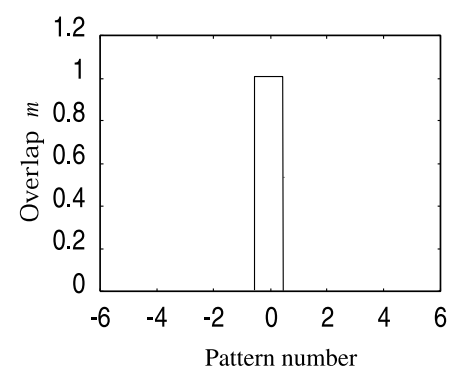

(a)

\section{3. 結果}

\section{1 相関アトラクター}

この節では $T=0$ とし, 相関アトラクターの定性的な 性質を説明する。これ以降, パターン数は $2 s+1=13$ とする. 初期状態を $\boldsymbol{\xi}^{0}$ とする. 非同期更新で $i$ 番目 のニューロンが選ばれたとすると，

$$
S_{i}=\operatorname{sgn}\left(\sum_{j \neq i} J_{i j} \xi_{j}^{0}\right)=\operatorname{sgn}\left(\xi_{i}^{0}+a\left(\xi_{i}^{1}+\xi_{i}^{-1}\right)\right),
$$

となり, $\xi^{0}$ が安定である条件は，

$$
a<\frac{1}{2},
$$

であることがわかる。これを計算機シミュレーション で確かめてみよう。計算機シミュレーションではニュー ロン数は $N=30,000$ とした. 図 1(a) に $a=0.4$ の 結果を示す。縦軸が, 式 (14) の状態 $\boldsymbol{S}$ と記憶パター ンのオーバーラップを平衡状態に関して表示したもの であり，横軸がパターン番号 $\mu$ をあらわす。平衡状態 でもオーバーラップは $m_{\mu}=\delta_{\mu, 0}$ であるので, $\boldsymbol{\xi}^{0}$ が 平衡状態であることがわる。 この平衡状態は Hopfield モデルの持つアトラクターと同じなので, 本論文では, このアトラクターを Hopfield アトラクターと呼ぶ.

次に $a>1 / 2$ の場合を議論しよう. $\xi_{i}^{1}$ と $\xi_{i}^{-1}$ が互 いに異符号であったり， $\xi_{i}^{0}$ と同符号である場合 $S_{i}=\xi_{i}^{0}$ となる。一方, $\xi_{i}^{1}$ と $\xi_{i}^{-1}$ が $\xi^{0}$ と異符号である場合, $S_{i}$ は $\xi^{0}$ と反対符号を持つ $\xi^{1}=\xi^{-1}$ をとる. これを オーバーラップの立場で説明すると, 系の状態 $\boldsymbol{S}$ は パターン $\boldsymbol{\xi}^{1}$ と $\boldsymbol{\xi}^{-1}$ とゼロでないオーバーラップを持 つことになる。この状態更新を繰り返すと, 平衡状態 としては二つの状態が考えられる。一つは, 前述のよ うにオーバーラップが隣のパターンに拡散していくの

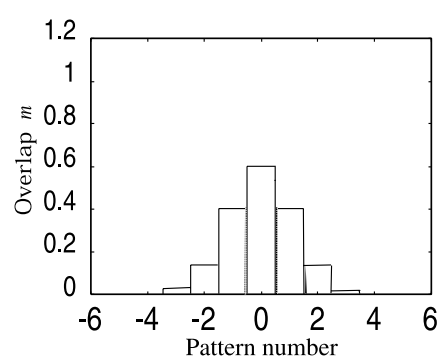

(b)

図 1 (a) Hopfield アトラクター : $a=0.4, N=30,000$. (b) 相関アトラクター : $a=0.6, N=30,000$. 
で, 最終的には系は全てのパターンと一様なオーバー ラップを持つ混合状態へ収束していくことが考えられ る.もう一つの可能性としては, 隣のパターンへの拡 散がとまり，初期状態に対応するパターンを中心とする ガウス分布状のオーバーラップの分布がえられること が考えられる. 図1(b)に, 平衡状態に扔ける各パ夕ー ンのオーバーラップの様子を示す. 図から明らかなよ うに, 平衡状態は初期状態に対応する 0 番目の記憶パ ターンを中心とするガウス分布状の分布を持つ. 初期 状態が 1 番目の記憶パターンである場合，それに対応 する平衡状態は 1 番目の記憶パターンを中心とするガ ウス分布状の分布を持つ。これら二つの平衡状態はあ る程度の相関を持つ。その相関は初期状態である記憶 パターン間の距離が離れるほど小さくなる。そこで, この図 1(b) に示されるような安定平衡状態を相関アト ラクターとよぶ.

\section{2 平衡状態}

式(11) $a=0.4$ として, オーバーラップ $\left\{m_{\mu}\right\}$ を 数值的に解いて求めた結果を図 2 に示す. 図の点線が Hopfield アトラクターのオーバーラップ $m_{0}$ を示す. Hopfield アトラクターは $T=0.1$ まで安定である。一 点鎖線が相関アトラクターの $m_{0}$ を示す. 式 (11) か ら明らかなように，オーバーラップは $\mu$ に関して奇 関数である $\left(m_{\mu}=m_{-\mu}\right)$. 図の実線は相関アトラク ターの $m_{0}$ 以外のオーバーラップを示し, 上から順番 に $m_{1}=m_{-1} \rightarrow m_{2}=m_{-2} \rightarrow \cdots \rightarrow m_{6}=m_{-6}$ で ある. 相関アトラクターは $T=0.25$ まで安定である. これまでの研究では $0.5<a<1$ のみで, 相関アトラ クターが存在するとされていたが, 式 (11)の数值的解 析から $a<0.5$ の範囲でも相関アトラクターが存在す ることがわかった．図からわかるように $T=0.1$ まで は, Hopfield アトラクターと相関アトラクターの二つ のアトラクターが安定である。さらに, 図 2 には記入 していないが, $T=0.05$ までは, 隣りあった三つの記 憶パターン数からなる混合状態も安定に存在する.さ らに $T=1.7$ までは 13 個の全ての記憶パターンから なる混合状態も安定である。

\section{3 ダイナミクス}

共存相：前節で述べたように, $a=0.4$ では $T=0.05$ までは, Hopfield アトラクター, 相関アトラクター, 記 憶パターン数 3 の混合状態, 記憶パターン数 13 の混 合状態がアトラクターとしてー共存する．これらのア トラクターの引き込み領域を式 (21) のオーバーラップ ダイナミクスの数值計算とシミュレーションを用いて 調べる. 初期状態としてはいろいろなものが考えられ

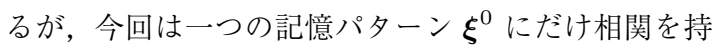

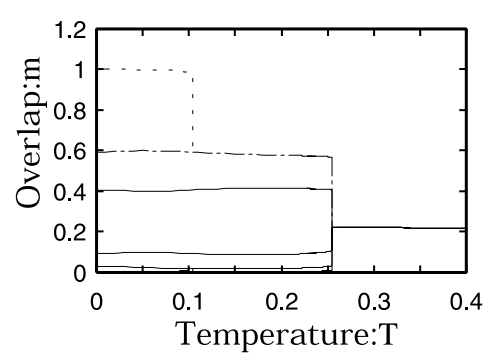

図2 点線が Hopfield アトラクターのオーバーラップ $m_{0}$ を示し, 一点鎖線が相関アトラクターの $m_{0}$ を 示す. 実線は相関アトラクターの $m_{0}$ 以外のオー バーラップを示し, 上から順番に $m_{1}=m_{-1} \rightarrow$ $m_{2}=m_{-2} \rightarrow \cdots \rightarrow m_{6}=m_{-6}$ を示す.

つような状態,

$$
m_{\mu}^{0}=m^{0} \delta_{\mu, 0}
$$

を初期状態として考える. 式 (24) を初期值にして, 式 (21)の微分方程式を数值的に解いた. また, 計算機シ ミュレーションでは, 初期状態 $\boldsymbol{S}^{0}$ を記憶パターン $\boldsymbol{\xi}^{0}$ から以下の確率を用いて生成し,

$$
\operatorname{Prob}\left[S_{i}= \pm 1\right]=\frac{1 \pm m^{0} \xi_{i}^{0}}{2},
$$

式 (1)〜(5)のモデルの初期状態とした。このようにし て求めた $\boldsymbol{S}^{0}$ のオーバーラップは $N \rightarrow \infty$ の極限では 式 (24) を満たす。結果を図 3 に示す. 図 3 の横軸は, 状態 $\boldsymbol{S}$ と記憶パターン $\boldsymbol{\xi}^{0}$ とのオーバーラップ $m_{0}$ を 示し, 縦軸は $\boldsymbol{\xi}^{1}$ とのオーバーラップ $m_{1}$ を示す. 式 (24)の初期状態は横軸上に存在する. Hopfield アトラ クターは $m_{0}$ だけが大きな值をとるので横軸上に存在 する. 相関アトラクターは, $m_{0}>m_{1}$ となるので, 図 の対角線より下側に存在する. また, この図には示して いないが, 記憶パターン $\boldsymbol{\xi}^{1}$ に関して, Hopfieldアトラ クターと相関アトラクターが存在する.この Hopfield アトラクターは縦軸上に存在し, 相関アトラクターは 対角線より上側に存在する. 初期状態として式 (24)の $m_{0}$ を 0.15 と 0.20 とした場合を計算した。 図 3(a) は 理論の数值計算の結果であり, (b) は $N=30,000$ の 計算機シミュレーションの結果である. 図に示すよう に, 初期オーバーラップ 0.15 の場合, 系は相関アト ラクターに収束し, 初期オーバーラップ 0.2 の場合, Hopfield アトラクターに収束する。つまり, 初期オー バーラップに関して 0.15 と 0.2 の間に臨界的な值 $m_{C}^{0}$ が存在し, それより小さい初期オーバーラップでは系 は相関アトラクターに収束し, 大きい場合は Hopfield 


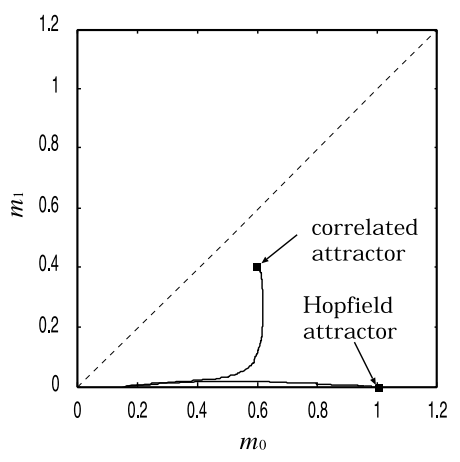

(a)

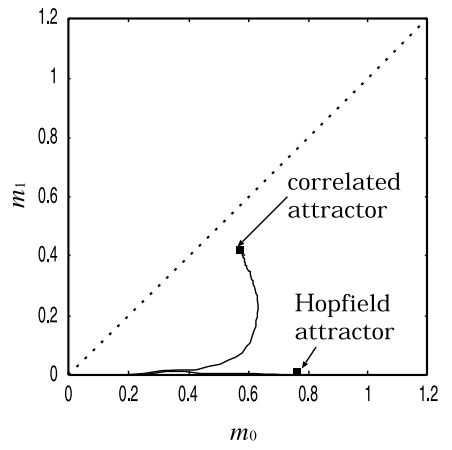

(b)

図3 $a=0.4, T=0.04$. (a) オーバーラップダイナミクスを数值的に解いた結果. (b) 計算機シミュレーション の結果 : $N=30,000$.

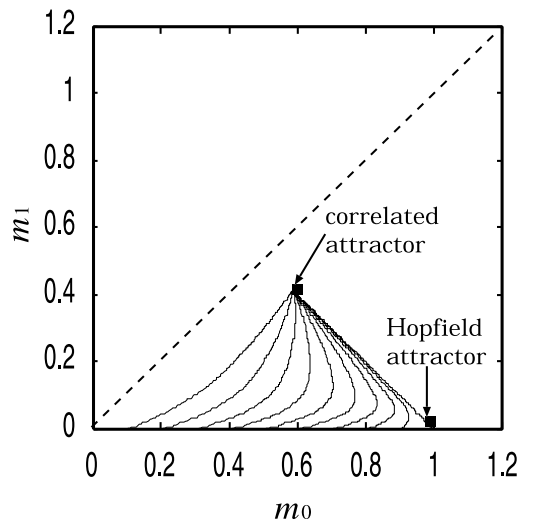

(a)

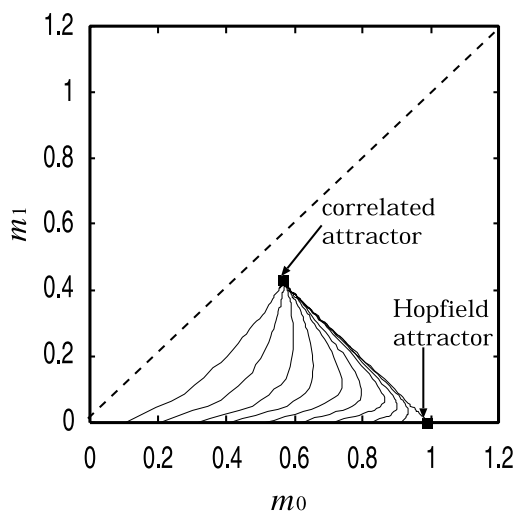

(b)

図 $4 a=0.4, T=0.15$. (a) オーバーラップダイナミクスを数值的に解いた結果. (b) 計算機シミュレーション の結果 : $N=30,000$.

アトラクターに収束することがわかった。式 (21) から $m_{C}^{0}$ を求めると $m_{C}^{0}=0.16$ であった. $m_{C}^{0}$ をいくら 小さくしても， $m_{C}^{0}>0$ であるかぎり，系はどちらか のアトラクターに収束した。つまり, 初期值として式 (24) の $m_{\mu}^{0}=m^{0} \delta_{\mu, 0}$ を用いる限り, 平衡状態の数值 計算により発見した $p=3$ の混合状態と $p=13$ の混 合状態へ収束しない.

Hopfield アトラクターが不安定な場合：図 3 を詳細に 見ると, 系が相関アトラクターに収束する場合でも, 初 期状態から直接的に相関アトラクターに収束していく のではなく，一度 Hopfield アトラクターに近付いてか ら相関アトラクターに収束している。この現象は, 最終 的に相関アトラクターに収束する場合でも, Hopfield ア トラクターが安定なので, 一度 Hopfield アトラクター に近付くと考えられる，そこで, Hopfield アトラクター
が不安定である場合の, 相関アトラクターへの収束過 程を調べた. 図 2 から $T=0.15$ にすると, Hopfield ア トラクターは不安定である。この場合にも, 式 (24)の 初期状態を用い, $m^{0}=0.1,0.2, \cdots, 0.9,1.0$ の場合に ついて, 相関アトラクターへの収束過程を調べた。図 4(a) と (b) に理論とシミュレーションの結果を示す. 図 の縦軸と横軸は図 3 と同じである. Hopfiled アトラク ターは不安定であるので, 初期状態を記憶パターン $\boldsymbol{\xi}^{0}$ としても $\left(m^{0}=1.0\right)$, 系の状態は $\boldsymbol{\xi}^{0}$ から離れていく. しかし, $m^{0}<1.0$ の初期状態から出発すると, 一度 Hopfield アトラクターが存在した $\left(m_{0}, m_{1}\right)=(1,0)$ に近付いてから，相関アトラクターに収束する。

\section{4. 議}

\section{論}

これらの理論的な結果から側頭葉のニューロンの知 
見についていて議論する.まずモデルの持つアトラク ターの双安定性から次の二つの実験の矛盾点を解決す る. Tanaka らや Fujita らはシングルセルレコーディ ングを用いて, 側頭葉の細胞は視覚物体の部分的な特 徵に選択的に反応することを示した ${ }^{1,4)}$. 一方, Gross のグループの Gochin らは，視覚的にまったく異なっ た刺激セットをもちいてニューロンの応答を調べた ${ }^{5)}$. その結果, ニューロンの応答の選択性は弱く, 多くの ニューロンはすべての刺激に応答し，ニューロン間の 違いは発火率が異なるという定量的なものであった。 サルの麻酔・無麻酔の状態などが，この矛盾を説明する 仮説としては用いられているが，それ以上明解な答は えられていない. 上の矛盾は側頭葉を単なる画像フィ ルターとして捉えたために生じたものである。もし側 頭葉を含む視覚系が力学系を構成しており，アトラク ターを使って視覚計算を行なっているとすれば, 系の 状態に応じて同じ入力に対して異なった応答が生じて も何ら不思議はない。 そこで我々は，この矛盾を説明 するためのモデルとして，ここで解析した Amit モデ ルを用いる ${ }^{6,7)}$. 前述の理論的な知見に基づき, 我々は Tanaka-Fujita 型のニューロンは Hopfield アトラクター に対応する応答をし, Gochin 型のニューロンは相関ア トラクターに対応する応答をするという仮説を提案し, それを検証する生理実験を提案する。

ここではニューロンのモデルとして \pm 1 をとる 2 值 ニューロンを考えたが, この Amit モデルに0-1 ニュー ロンとスパースコーディングを用いた場合を考えよう. Griniasty らはこのスパースコーディングを用いたモデ ルでも, 相関アトラクターが存在することを示してい $ろ^{6)}$. このモデルにも今回の知見と同様に, 相関アト ラクターと Hopfield アトラクターの双安定性を仮定す る。スパースコーディングの場合, 一つの画像に応答 するニューロンの数は少なくなる．その応答を実験的 に観測すれば，ある特徵に選択性を持つ応答に見える。 つまり，スパースコーディングを仮定すると，ニューロ ン集団が Hopfield アトラクターに対応する状態にいれ ば，個々のニューロンは Tanaka-Fujita 型の特徵選択性 を示す。実は，この仮説は Tanaka らや Fujita らの実験 パラダイムにも符合する。彼らは複雑な視覚刺激から 徐々に単純な四形をリダクションする方法で, ニュー ロンの選択性を精密に決めている。ニューロン集団へ の入力刺激としては, それらのニューロンに適した，つ まり，オーバーラップの大きな入力を選んでいること になる，その場合，我々の知見では系はHopfield アト ラクターに収束する。この状態をニューロンの応答で 考えると, ニューロンはある特定の刺激に応答し, 特徵
選択性は強い. この性質は Tanaka らや Fujita らの知 見に一致する。一方, Gochin らは, Tanaka らや Fujita らとは異なり, あらかじめ決めた画像の組を用意し, それらに対するニューロンの応答を調べた. Gochin ら は, ニューロンがどのように学習されているかを考慮 せずに刺激画像を選んだのに対し, Tanaka らや Fujita らはリダクションの方法でニューロンの学習した画像 を選んで視覚刺激にしたのである.Gochin らの刺激は ニューロンにそれほど最適ではない,つまり, オーバー ラップの小さな入力に対応している。 その場合, 我々 の知見では系は相関アトラクターに収束する。この状 態をニューロンの応答で考えると, ニューロンはいろ いろな刺激に応答し, 特徵選択性は低下する。この性 質は, Gochin らの知見に一致する。これら二つの矛盾 する実験を説明するこの仮説を検証する電気生理実験 を提案する。まずTanakaらやFujitaらの用いたリダク ションの方法でニューロンの最適刺激を決定する. そ の刺激に Shidara $ら^{11)}$ や Amit $ら^{12)}$ が行なっているよう にノイズを重畳する。ニューロンの刺激選択性を，そ のノイズの量を変えて測定すると, 単にその刺激に対 してニューロンの応答が下がるのではなく, 他の刺激 にも応答し始めて, 選択性が下がることが観測される はずである。

次に，相関アトラクターへの想起過程の知見から， Miyashita らの遅延見本合わせ課題のニューロンの過渡 特性を解析することを提案する. 彼らの実験では記憶 保持中のニューロンの応答の定常的な部分を解析し, 前 述の結果を得ている。ニューロンの過渡応答特性を調 ベるには, Sugase ら ${ }^{9)}$ や Matsumoto ら ${ }^{10)} の$ 解析のよう にニューロン応答をある程度細かなビンに刻み, その ビン中の平均発火率の変化を解析すれば良い. Sugase らは入力刺激とビン中のニューロン発火の相互情報量 を計算することにより, 相互情報量の時間変化を計算 した. Matsumotoらはビン中の平均発火率からニュー ロン集団の発火状態を表すべクトルを計算し, 主成分 分析やクラスタリング手法を用いて, ニューロン集団 の情報表現の時間変化を求めている。このような方法 を, Miyashita らの遅延見本合わせ課題のニューロンの 応答に適用すれば，もしその系が Amit モデルで記述 できるのなら, ニューロンの集団の挙動が Hopfield 型 から相関アトラクター的な表現に変化しているのが見 えるはずである。

\section{参 考 文 献}

1) Tanaka, K., Saito, H., Fukada, Y., and Moriya, M. (1991): Coding visual images of objects in the in- 
ferotemporal cortex of the macaque monkey. Journal of Neurophysiology, Vol.66, pp.170-189

2) Miyashita, Y., and Chang, H.S. (1988): Neuronal correlate of pictorial short-term memory in the primate temporal cortex. Nature, No.331, pp.68-70

3) Miyashita, Y. (1988): Neuronal correlate of visual associative long-term memory in the primate temporal cortex. Nature, No.335, pp.817-820

4) Fujita, I., Tanaka, K., Ito, M., and Cheng, K. (1992): Columns for visual features of objects in monkey inferotemporal cortex. Nature, No.360, pp.343-346

5) Gochin, P.M., Colombo, M., Dorfman, G.A., Gerstein, G.L., and Gross, C.G. (1994): Neural ensemble coding in inferior temporal cortex. Journal of Neurophysiology, Vol.71, pp.2325-2337

6) Griniasty, M., Tsodyks, M.V., and Amit, D.J. (1993): Conversion of temporal correlations between stimuli to spatial correlations between attractors. Neural Computation, Vol.5, pp.1-17

7) Amit, D.J., Brunel, N., and Tsodyks, M.V. (1994): Correlations of cortical Hebbian reverberations: theory versus experiment. Journal of Neuroscience, Vol.14, pp.6435-6445
8) Fukai, T., Kimoto, T., Doi, M., and Okada, M. (1999): Coexistence of uncorrelated and correlated attractors in a nonmonotonic neural network. Journal of Physics A: Mathematical and General, Vol.32, pp.5551-5562

9) Sugase, Y., Yamane, S., Ueno, S., and Kawano, K. (1999): Global and fine information coded by single neurons in the temporal visual cortex. Nature, No.400, pp.869-873

10) Matsumoto, N., Okada, M., Doya, K., Sugase, Y., and Yamane, S. (2001): Dynamics of face responsive neurons in the temporal cortex. In Society for Neurosciece abstracts, No.27, 398.5 Matsumoto, N. and Okada, M., Neuronal Mechanisms for hierarchical encoding in inferior-temporal cortex. to be published in Neurocomputing.

11) Shidara, M., Liu, S., and Richmond, B.J. (1996): Stimulus degradation has a similar effect on stimulus related information in inferior temporal (IT) neurons and on the monkey's behavior. In Society for Neurosciece abstracts, No.22, p.1615

12) Amit, D.J., Fusi, S., and Yakovlev, V. (1997): Paradigmatic working memory (attractor) cell in IT cortex. Neural Computation, Vol.9, pp.1071-1092 